Karmina Miteva ${ }^{1 *}$, Slavčo Aleksovski ${ }^{1}$, Gordana Bogoeva-Gaceva ${ }^{1,2}$

${ }^{1}$ Ss "Cyril and Methodius" University in Skopje, Faculty of Technology and Metallurgy, Skopje, Republic of Macedonia,

${ }^{2}$ Research Center for Environment and Materials, Macedonian Academy of Sciences and Arts, Skopje, Macedonia
Scientific paper

ISSN 0351-9465, E-ISSN 2466-2585

UDC:620.193.4:665.658.6

doi:10.5937/ZasMat1604600M

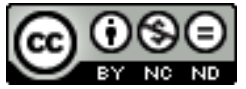

Zastita Materijala 57 (4)

$600-604$ (2016)

\title{
Catalytic pyrolysis of waste plastic into liquid fuel
}

\begin{abstract}
Process of pyrolysis is a thermochemical process conducted at high temperatures and usually in presence of catalysts. Different type of catalysts, natural and synthetic, can be used for conversion of organic wastes into valuable fuels. The aim of this work is conversion of waste polyolefin mixture and production of liquid fuel using mixture of $\mathrm{Al}_{2} \mathrm{O}_{3}$ and $\mathrm{SiO}_{2}$ as a catalyst. Waste mixture was pyrolyzed at temperature range $400-550^{\circ} \mathrm{C}$ and obtained products were liquid fuel, gas and minor solid residue. Under the optimized reaction conditions, the condensed liquid fraction is much larger than the gaseous fraction. Different amounts of catalyst and polyolefin mixture as a feedstock were used. According to the obtained results, the retention time and the percent of $\mathrm{SiO}_{2}$ in the catalyst mixture have predominant effect on the amount of liquid product. Decreasing the quantity of $\mathrm{SiO}_{2}$ in the catalyst mixture increased the yield of liquid product. The physical properties of obtained liquid products were characterized and according to the measured values, liquid fuel belongs to light fraction of diesel fuel.
\end{abstract}

Keywords: Pyrolysis, waste plastic, catalytic conversion, fuel, physical properties.

\section{INTRODUCTION}

Today, plastics materials are very frequent in daily life and provide a fundamental contribution to our society. The typical distribution of household plastics as a part of the overall solid waste stream is: polyolefins $66.9 \%$, polystyrene $13.3 \%$, PVC $10.3 \%$, PET $5.3 \%$ and others $4.2 \%$. Waste plastic ends its lifetime as municipal solid waste on the landfill [1]. Over the world plastic waste has continuously grown in the last decades. Disposal of waste plastics causes serious environmental problems. Thus, plastic waste recycling has been a focus of many researchers in the past few decades. Pyrolysis appears to be promising technic of conversion of solid wastes plastic (SWP) to more usable materials such as gas fuel and/or fuel oil or to high value feedstock for the chemical industry. Degradation of the waste plastic materials, by heating in an inert atmosphere-pyrolysis, is usually

\footnotetext{
${ }^{\star}$ Corresponding author: Karmina Miteva

E-mail: karminamiteva@gmail.com

Paper received: 20. 06. 2016.

Paper accepted: 27. 08. 2016.

Paper is available on the website: www.idk.org.rs/journal
}

conducted at moderate temperatures between $400-800^{\circ} \mathrm{C}$. Obtained products are volatile condensable hydrocarbon oil and a noncondensable high calorific value gas [2]. The dominant components of domestic plastics are rich in carbon and hydrogen so that there is a good possibility for converting waste plastic into liquid fuels [3]. The extent of reaction, oil yield, and its composition depend on the type of plastic and process conditions [4]. Thermal pyrolysis of plastic materials leads to a wide product distribution and requires high degradation temperatures [5]. During the cracking process of long polymer molecules the degradation of polymer chains can be enhanced by applying of various catalysts. The catalytic pyrolysis of plastic wastes gives valuable products similar to diesel and gasoline [6]. The most frequently used catalysts are zeolites and mesoporous materials because of their porous structure and acid properties [7]. In the case of the polyolefin catalytic cracking like HDPE and PP a number of acid porous solids, such as amorphous silica-alumina, zeolites and ordered mesoporous materials, have been used as catalysts [5-7]. The used catalysts have high conversion effect over the 
plastic wastes at lower temperature and decrease the activation energy [8]. Many researchers studied the catalytic degradation of polymer wastes in the last decades. The addition of catalyst is expected to reduce decomposition temperature and to modify the products. Different types of reactors has been used for pyrolysis of waste plastic like, batch [9] or autoclaves [10] semi-batch [11], screw conveyors or fluidized beds [12] and fixed beds [13], shaft kilns or rotary kilns[14]. Most studies are carried out in beds or batch processes where all products are collected as a single sample, and subsequently analyzed. Often focus of the studies is effect of experimental conditions (reaction temperature and time) on product yield and composition [14,15], but others are focused on characterization of obtained products.

The aim of this work is catalytic conversion of high density polyethylene (HDPE) and polypropylene (PP) waste mixture into liquid products that could be used as fuel and feedstock for chemical industries. The process of pyrolysis was carried out in the presence of mixture $\mathrm{Al}_{2} \mathrm{O}_{3}$ and $\mathrm{SiO}_{2}$ catalysts using a semi-batch reactor. Emphasis will be given to high conversion of waste plastic to liquid products. Different amounts of catalysts and polyolefin mixture were used (Table 1). The physical properties of obtained liquid products also were determinate.

\section{EXPERIMENTAL}

\subsection{Materials}

Waste mixture of polyethylene and polypropylene was used as a raw material. The plastic mixture $(75 \% \mathrm{PE}$ and $25 \% \mathrm{PP}$, assigned as RW in further text), was supplied by a plastic recycling company in the form of post-consumer plastic pellets. The samples were re-granulated by manufacturers. The polymer mixture pellets have maximum particle size of $5-6 \mathrm{~mm}$. The melting temperatures of HDPE+PP mixture, as determined by DSC, were $127^{\circ} \mathrm{C}$ and $163^{\circ} \mathrm{C}$, respectively. The purched pelletized catalyst $(5 \mathrm{~mm})$ of $\mathrm{Al}_{2} \mathrm{O}_{3}$ (assigned as $\mathrm{A}$ in further text) has specific surface
$400 \mathrm{~m}^{2} / \mathrm{g}$. The specific surface area of $\mathrm{SiO}_{2}$ (assigned as $\mathrm{S}$ ) is $39.3 \mathrm{~m}^{2} / \mathrm{g}$. To remove traces of adsorbed water in $\mathrm{SiO}_{2}$ and $\mathrm{Al}_{2} \mathrm{O}_{3}$, both catalysts were dried at $110^{\circ} \mathrm{C}$ around $2 \times 3 \mathrm{~h}$ before they were used.

\subsection{Experimental Setup}

All catalytic degradation experiments of waste polyolefin mixture (RW) were carried out in a stainless steel semi-batch reactor with $400 \mathrm{~mL}$ volume which was equipped with temperature measurement system. Different amounts of plastic waste mixed with catalyst were placed into a reactor. The reaction system was closed at atmospheric pressure and then the heater was switched on. The pyrolysis was carried out from $18^{\circ} \mathrm{C}$ to maximum of $550^{\circ} \mathrm{C}$ for around $3 \mathrm{~h}$. The pyrolytic experiments were carried out under dynamic conditions using $10^{\circ} \mathrm{C} / \mathrm{min}$ heating rate and different retention time on previously set temperature program. The temperature was control using PID (Unitronics V570) temperature controller. The obtained vaporized products from reactor were collected through a deep stainless pipe that reached down to the bottom of the semi-batch reactor afterwards being let out to a system of condensers in order to condense the condensable products. A glass condensers were connected tightly to the reactor to cool the condensing vapors from the reactor. Dynamic of pyrolysis process was monitored by time measuring the volume of collected oil. Obtained liquid products were collected into condensers and then were analyzed. Almost all condensable products were collected at the first condenser. Depending of operating conditions, sometimes in the second condenser was observed occurrence of condensate. The condensed liquid products appear over $410^{\circ} \mathrm{C}$.

\section{RESULTS AND DISCUSSION}

Table 1 depicted the amounts of liquid products obtained for different catalyst ratio and temperature programs. From obtained results the influence of temperature program is evident.

Table 1 - The amounts of liquid products and process conditions

\begin{tabular}{|c|c|c|c|c|c|}
\hline $\begin{array}{c}\text { sample } \\
\text { No }\end{array}$ & $\begin{array}{c}\text { raw mixture } \\
\mathrm{m}[\mathrm{g}]\end{array}$ & $\begin{array}{c}\text { raw mix : catalysts } \\
(\mathrm{RM}: \mathrm{A}: \mathrm{S})\end{array}$ & $\begin{array}{c}\text { liquid oil } \\
\text { V condenser } 1\left[\mathrm{~cm}^{3}\right]\end{array}$ & $\mathrm{Y}[\%]$ condenser 1 & PID program \\
\hline 1 & 30.05 & $1: 1: 4.5$ & 29.5 & 77 & 1 \\
\hline 2 & 30.01 & $1: 1: 4.5$ & 34.5 & 88 & 2 \\
\hline 3 & 50.39 & $2: 1: 4.5$ & 50 & 78 & 1 \\
\hline 4 & 60.22 & $6: 1: 1$ & 72 & 88 & 2 \\
\hline
\end{tabular}

Figure 1 shows the temperature programs of PID controller. The temperature program No: 1 is longer than program No: 2 which slower reaches the cracking temperature interval $\left(380^{\circ} \mathrm{C}-430^{\circ} \mathrm{C}\right)$ 
according to the previous made TGA analysis [16]. The TGA-DTG analysis showed that maximum weight lost occurred at $430^{\circ} \mathrm{C}$ and the weight changes start at $310^{\circ} \mathrm{C}$ to $500^{\circ} \mathrm{C}$. The purpose of using two different PID programs was to find out a suitable program for maximum production of liquid product.

From the aforementioned comparison the dependence of obtained liquid yield with retention time at set temperatures in the cracking temperature interval is evident. A higher liquid yield is obtained using second (No 2) PID temperature program. According to that finding the most important thing is proper choice of PID program. This means a long enough retention time into a cracking temperature interval in order to complete the cracking of long molecules of plastic polymer to smaller molecules of hydrocarbons with range of C5-C16 (the range of petroleum fuels, diesel and gasoline).

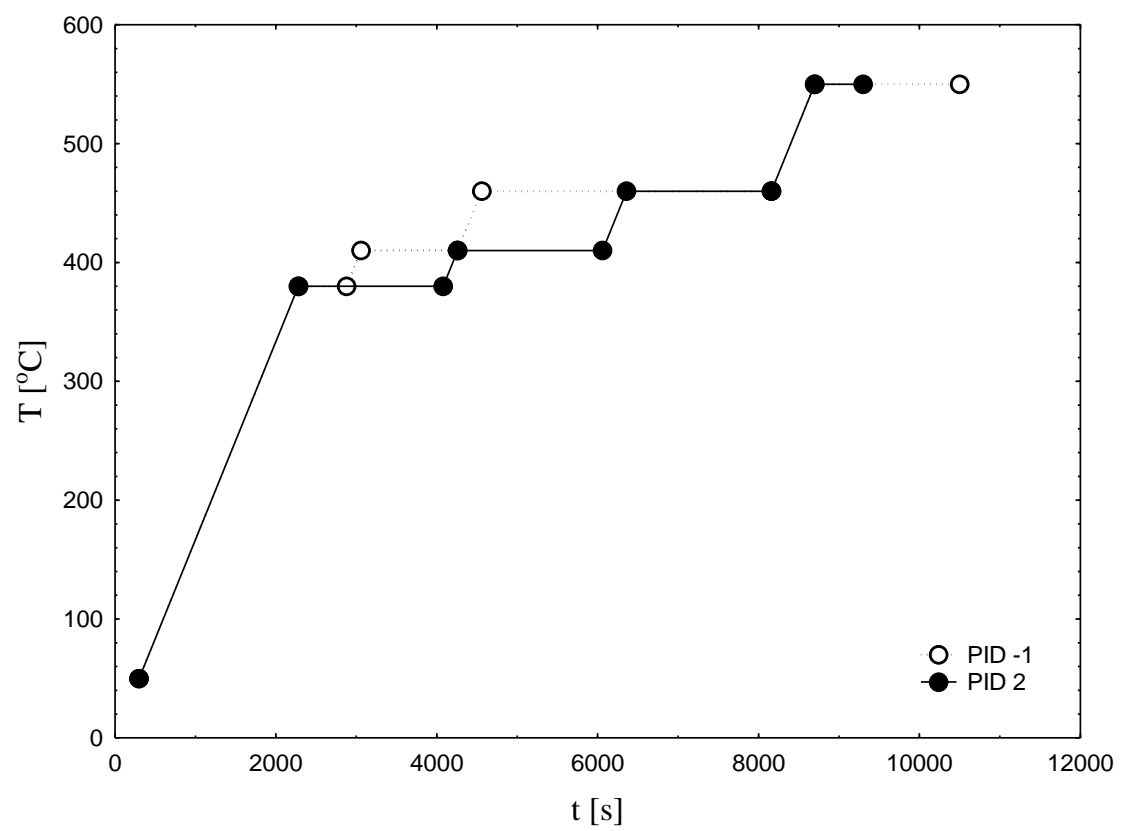

Figure 1 - Temperature program of PID controller

The same finding is observed for samples when the initial mass increase but the liquid yield decreased if it is the first PID program. The liquid yield is higher for samples which are decomposed using the second temperature program regardless of initial mass of sample or catalyst (Table 1). Even so reduction of mass of catalyst and the increases of initial mass of samples have no effect on the obtained liquid yield if second temperature program is chosen (sample No 4). The whole retention time of sample in the reactor is very important and it has great influence on the final liquid yield. It is confirmed that longer retention time at few lower temperatures $\left(380^{\circ} \mathrm{C}\right.$ and $\left.410^{\circ} \mathrm{C}\right)$ before the vapors starts exhausted from the reactor at $430^{\circ} \mathrm{C}$ gives higher liquid yield. The time and temperature dependence of the product yield for sample No 2, as a representative sample, using PID-2 temperature program is depict on Figure 2-a and 2-b.

Some of physical properties of oil sample measured according to specified ASTM test method are shown in Table 2.

Table 2 - Physical properties of HDPE and PP pyrolytic oil

\begin{tabular}{|c|c|c|c|c|}
\hline Sample, No & viscosity at $40^{\circ} \mathrm{C},\left[\mathrm{mm}^{2} / \mathrm{s}\right]$ & density at $20^{\circ} \mathrm{C}\left[\mathrm{g} / \mathrm{cm}^{3}\right]$ & aniline point, $\left[{ }^{\circ} \mathrm{C}\right]$ & index of refraction \\
\hline 1 & 1.0734 & 0.7762 & 63.5 & 1.4408 \\
\hline 2 & 0.8335 & 0.7694 & 63 & 1.4407 \\
\hline 3 & 1.2099 & 0.7800 & 65 & 1.4451 \\
\hline $4-I$ & 0.8418 & 0.7661 & 63 & 1.4349 \\
$4-I$ & 0.9402 & 0.7775 & 61 & 1.4436 \\
\hline
\end{tabular}



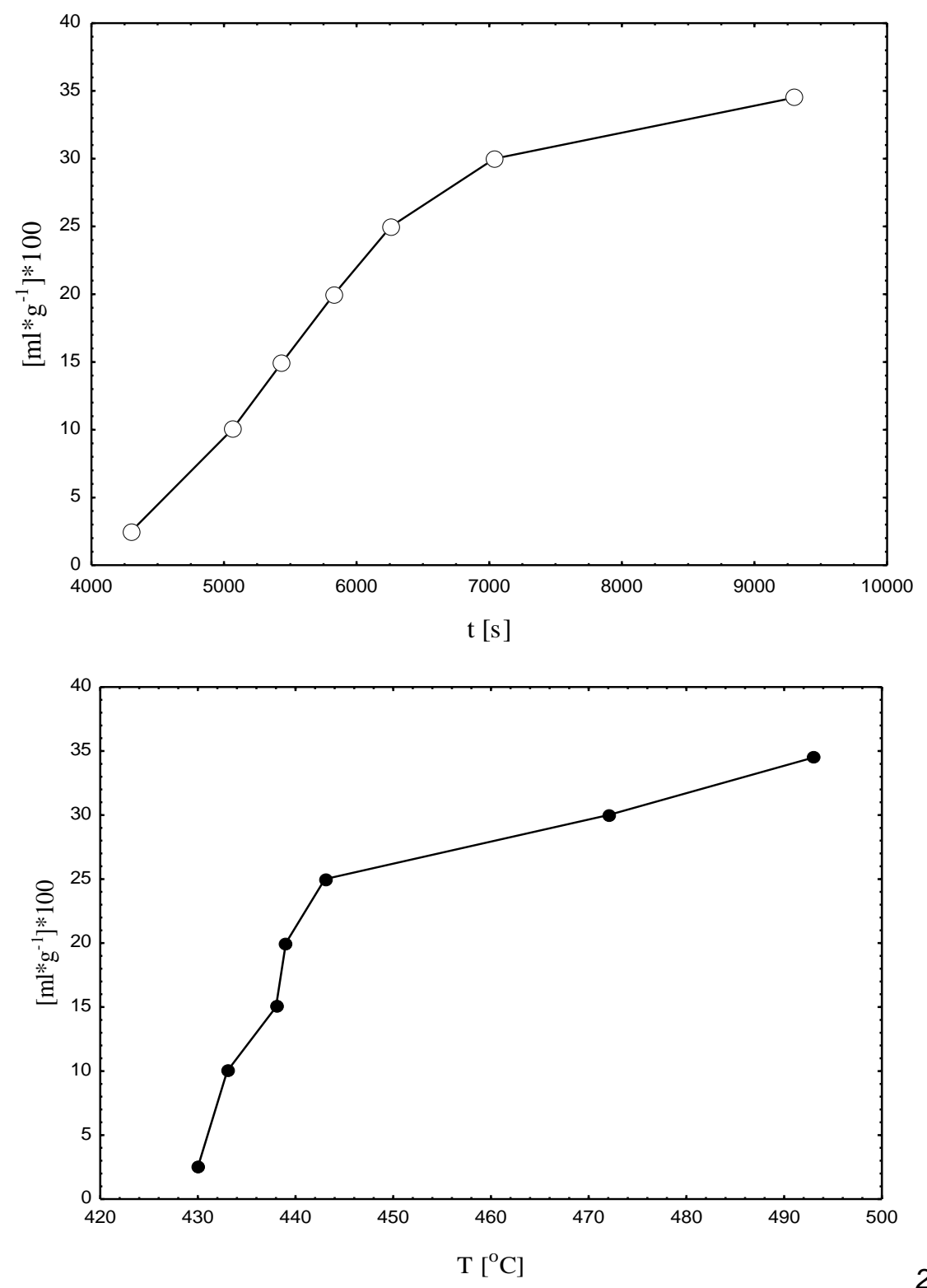

$2 b$

Figure 2 - Influence of: a-reaction time; $b$ - reaction temperature, on the yield of liquid fuel for sample No 2 , as a representative sample, using PID 2 temperature program

From above observation, it is clear that the waste plastic is able to give the liquid products which are with the same values of physical parameters as gasoline or kerosene fuels. The operating conditions are related with physical properties of obtained liquid fuel. As we can see from Table 2 the lower values of all physical properties was measured for samples 2 and 4 produced using second temperature program, which confirms the previous conclusion about temperature program and retention time. Also, these results confirm that different PID programs give various products, gasoline or diesel fractions. According to density results, samples 2 and 4 (4-I, first fraction of sample) are in the ultimate gasoline range $\left(\rho=0.71-0.77 \mathrm{~g} / \mathrm{cm}^{3}\right)$ and samples 1 and 3 are in range of kerosene $\left(0.78-0.82 \mathrm{~g} / \mathrm{cm}^{3}\right)$. Other measured values of the rest physical properties are close to each other and belong in kerosene range. Therefore it can be concluded that obtained liquid fuels are first diesel fraction - kerosene.

\section{CONCLUSION}

From this research work, it is clear that the waste plastic is able to give the high yield $(77-88 \%)$ of liquid product by using semi-batch reactor. The produced oil product easily can be fractionated into gasoline, petrol or kerosene. The employed mixture of $\mathrm{Al}_{2} \mathrm{O}_{3}$ and $\mathrm{SiO}_{2}$ as a catalyst successfully converts waste plastic into liquid fuel. Higher yield of liquid products was obtained for the temperature above $430^{\circ} \mathrm{C}$. The fuel oil formation is greatly 
affected by the proper choice of PID program, a long enough retention time at previously determinate cracking temperature interval. Physical properties and yield of obtained liquid fuel are related with the operating conditions. Measured physical properties indicate that liquid fuels represent the first diesel fraction - kerosene.

\section{REFERENCES}

[1] W.Kaminsky, I.Nuñez Zorriqueta (2007) Catalytical and thermal pyrolysis of polyolefins, Journal of Analytical and Applied Pyrolysis, 79, 368-374.

[2] S.A.Ammar, D.A.Sawsan Shubar (2008) Pyrolysis of high-density polyethylene for the production of fuel-like liquid hydrocarbon, Iraqi Journal of Chemical and Petroleum Engineering, 9 (1), 23-29.

[3] L.Ballice, M.Yuksel, M.Saglam, R.Reimert, H.Schulz (1998) Classification of volatile products evolved during temperature programmed co-pyrolysis of Turkish oil shales with low density polyethylene, Fuel, 77(1-3), 1431-1441.

[4] M.Sarker., M.M.Rashid, M.S.Rahman (2012) High density polyethylene (HDPE) waste plastic conversion into alternative fuel for heavy vehicles Journal of Environmental Research and Development , 7(1), 1-9.

[5] R.AGarcía., D.P.Serrano, D.Otero (2005) Catalytic cracking of HDPE over hybrid zeolitic-mesoporous materials, Journal of Analytical and Applied Pyrolysis, 74(1-2), 379-386.

[6] A.Marcilla, F.Go'mez-Siurana, J.Valde's (2008) Influence of the temperature on the composition of the coke obtained in the catalytic cracking of low density polyethylene in the presence of USY and HZSM-5 zeolites, Microporous and Mesoporous Materials, 109, 420-428.

[7] B.W.Wojciechowski, A.Corma (1986) Catalytic cracking catalyst, Chemistry and Kinetics, Marcel Dekker, Inc. New York,.
[8] M.N.Almustapha, M.John Andrésen (2012) Recovery of valuable chemicals from high density polyethylene (HDPE) polymer: a catalytic approach for plastic waste recycling, International Journal of Environmental Science and Development, 3(3), 263-267.

[9] M.A.Usman, T.O.Alaje, V.I.Ekwueme, T.E.Adekoya (2012) Catalytic degradation of water sachet waste (LPDE) using mesoporous silica kit- 6 modified with 12-tungstophosphoric acid, Petroleum \& Coal, 54 (2), 85-90.

[10] S.Moinuddin, M.M.Rashid, M.R.Sadikur, M.Molla (2012) A new kind of renewable energy: production of aromatic hydrocarbons naphtha chemical by thermal degradation of polystyrene (PS) waste plastic, American Journal of Climate Change, 1, 145-153.

[11] L.Kyong-Hwan, S.Dae-Hyun, S.Jeong-Kwon (2005) Catalytic degradation of waste-high density polyethyleneinto liquid product, Environmental Engineering Research, 10(2), 54 -61.

[12] J.S.Kim (2004) Pyrolysis of plastic waste using the non-catalytic hamburg-process and the catalytic process using the cycled-spheres-reactor, Environmental Engineering Research, 9(1), 31-37.

[13] M. Artetxe, G.Lopez, M. Amutio, G.Elordi, J.Bilbao, M.Olazar (2012) Light olefins from HDPE cracking in a two-step thermal and catalytic process, Chemical Engineering Journal, 207-208, 27-34.

[14] D.P.Serrano, J.Aguada, J.M.Escola, E.Garagorri (2001) Conversion of low density polyethylene into petrochemical feedstocks using a continuous screw kiln reactor, Journal of Analytical and Applied Pyrolysis, 58-59, 89-801.

[15] S.Moinuddin, M.M.Rashid (2013) Food container waste plastic conversion into fuel, International Journal of Engineering and Applied Science, 3(1), 1-7.

[16] K. Miteva, S.Aleksovski, G.Bogoeva-Gaceva (2015) Kinetic study of pyrolysis of waste polyolefine mixture using integral fitting kinetic model, ICSD, Belgrade, Serbia, proceedings, 235-242.

\section{IZVOD}

\section{KATALITIČKA PIROLIZA OTPADNE PLASTIKE U TEČNO GORIVO}

Proces pirolize je termohemijski postupak koji se izvodi na visokim temperaturama $i$ obično $u$ prisustvo katalizatora. Različite vrste katalizatora, prirodnih i sintetičkih, može se koristiti za konverziju iz organskog otpada u vredna goriva. Cilj ovog rada je konverzija otpada poliolefinske mešavine u proizvodnju tečnih goriva, koristeći mešavinu $\mathrm{Al}_{2} \mathrm{O}_{3}$ i $\mathrm{SiO}_{2}$ kao katalizator. Mešavina otpada je podvrgnuta procesu pirolize u temperaturnom opsegu $400-550^{\circ} \mathrm{C}$ i dobijeni proizvodi su tečno gorivo, gas i malo čvrsti ostatak. Pod optimalnim reakcionim uslovima, kondenzovana tečna frakcija je mnogo veća od gasovite frakcije. Korišćene su različite količine katalizatora $i$ poliolefinske mešavine kao sirovine. Prema dobijenim rezultatima, retenciono vreme i procenat $\mathrm{SiO}_{2}$ u katalizatorskoj smeši imaju dominantan uticaj na iznos tečnog proizvoda. Smanjenje količine $\mathrm{SiO}_{2}$ u smeši katalizatora poveća prinos tečnog proizvoda. Fizičke osobine dobijenih tečnih proizvoda su okarakterisane po izmerenoj vrednosti. Tečno gorivo spada u lake frakcije dizel goriva.

Ključne reči: piroliza, otpadna plastika, katalitička konverzija, gorivo, fizička svojstva.

\section{Naučni rad}

Rad primljen: 20. 06. 2016.

Rad prihvaćen: 27. 08. 2016.

Rad je dostupan na sajtu: www.idk.org.rs/casopis 